УДК 005.322:316.46:005.912

DOI: $10.15673 /$ fie.v11i1.1298

\author{
Корсікова Н.М. \\ кандидат економічних наук, доцент \\ E-mail:nkorsikova@ukr.net \\ ORCID ID: 0000-0002-1649-4725 \\ Череватий В.М. \\ магістрант \\ кафедра менеджменту і логістики \\ Одеська національна академія харчових технологій \\ вул. Канатна, 112, м. Одеса, Україна, 65039 \\ E-mail: v_cherevatyi@ukr.net
}

\title{
СИСТЕМНИЙ ПІДХІД ДО ПІДВИЩЕННЯ ОСОБИСТОЇ ЕФЕКТИВНОСТІ СУЧАСНОГО КЕРІВНИКА
}

В статі розглянуто актуальність та основні аспекти роботи сучасного керівника, його місце та значущість в суспільстві. Виділено особливі проблеми, які значною мірою впливають на поведінку, а відповідно, і на рішення, які повинен приймати керівник. Увага приділена визначенню основних вимог до компетенцій сучасного менеджера. 3 огляду на складність і багатоаспектність наведеної системи вимог і компетенцій, виділено кілька основних аспектів самоменеджменту, як сучасної наукової системи знань з розвитку і підвищенню особистої ефективності керівника. У роботі охарактеризовано основні концептуальні погляди на проблеми самоменеджменту, запропоновано звернути увагу на окремі практичні методичні прийоми реалізації кожного концептуального напрямку. Автори приходять до висновку, що саме комплексний, системний підхід до процесу підвищення особистої ефективності і саморозвитку дає можливість керівникові отримати від своєї діяльності не тільки значного професійного ефекту, але й задоволення від самого процесу роботи.

Ключові слова: особиста ефективність, керівник, компетенції, самоменеджмент, таймменеджмент, особистий розвиток.

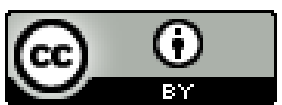

This work is licensed under a Creative Commons Attribution 4.0 International License http://creativecommons.org/licenses/by/4.0/
Постановка проблеми та зв'язок з важливими науковими та практичними завданнями. Менеджмент як наукова система управління сьогодні $є$ однією з найважливіших умов ефективної і прибуткової діяльності будь-якої організації. Однак, насправді, якісно й ефективно організувати роботу інших завдання не $з$ простих. Для цього необхідні талант, знання та уміння, які ефективний менеджер повинен розвивати протягом всього життя.

Крім того, сучасний світ ставить перед людством низку проблем, які мають вплив на всі аспекти життєдіяльності будь-якої людини, а особливо керівника:

- стреси, тиск зовнішнього середовища і невизначеність, що змушує людину шукати шляхи підвищення свого рівня стресостійкості, посилювати увагу до стану фізичного та психологічного здоров'я;

- ерозія традиційних цінностей i, як наслідок, серйозний розлад особистих переконань і цінностей;

- широка можливість вибору цілей, методів їх реалізації, засобів впливу на оточуючих тощо, що обумовлює необхідність чіткого визначення особистих цілей і завдань;

- незважаючи на широкий спектр освітніх, навчальних та інших послуг, сьогодні жодна органі- заційна система не в змозі забезпечити всі можливості для навчання, які потрібні сучасному керівнику, тому кожна людина повинна сама підтримувати постійне власне зростання і розвиток;

- коло нагальних проблем стає все більше, i вони все складніше, в той час як засоби їх вирішення - найчастіше більш обмежені. Тому саме здатність вирішувати проблеми швидко і ефективно стає все більш важливою частиною управлінських навичок;

- обмеженість ресурсів, поширення конкуренції на ринках, при одночасному розширенні можливих сфер застосування наявних ресурсів, роблять необхідним постійний пошук нових ідей, постійного пристосування до змін, швидкість яких ще з середини 70-х років XX століття прискорилась майже в шість разів у порівнянні з початком XX сторіччя [1]. «Ресурси більше не обмежують рішення. Сьогодні рішення створюють ресурси» [1, с.27];

- традиційні ієрархічні відносини бюрократичної організації стають все менш ефективними, що потребує робити акцент на командній роботі на основі паритетних відносин, а відповідно, посилюється увага до характеристик та навичок психологічного характеру; 
- традиційні школи і методи управління втрачають свої позиції і не відповідають викликам сьогодення і майбутнього. Тому потрібні нові, більш сучасні управлінські прийоми, які, з одного боку, відповідали б поточним викликам майже перманентного кризового стану економіки і суспільства в цілому, а, 3 іншого боку, спрямовували організацію на довгострокову стратегічну перспективу;

- складні проблеми у все більшій мірі потребують об'єднання зусиль багатьох людей. Синергізм стає найбільш рушійною силою розвитку як організації як системи, так і особистості кожного працівника. Але ж формування такої єдиної компанії потребує від менеджера неабияких зусиль.

Саме ці обставини, які були узагальнені відомими англійськими дослідниками та бізнесконсультантами М.Вудкоком і Д.Френсісом [2], безумовно ускладнюють, в міру зростання їх масштабів і розвитку виробництва, завдання та вимоги до сучасного менеджера. Тому сьогодні назріла необхідність формування нових наукових підходів до формування і розвитку сучасного ефективного керівника.

Як підвищити особисту ефективність? Саме на вирішення цієї проблеми спрямовані сьогодні думки і зусилля багатьох науковців і практиків в сферах психології та управління персоналом.

Аналіз останніх публікацій по проблемі. Саме визначення особистої ефективності $\epsilon$ досить «розмитим», не має чіткого визначення. Але, як правило, воно визначається як здатність людини виконувати певні завдання максимально швидко і якісно, тобто пов'язується з витратами часу.

I на сьогодні питанню раціонального використання часу присвячено більшість досліджень і публікацій у відносно новій управлінській науці - самоменеджмент. Більшість фахівців і теоретиків сучасного менеджменту сходяться на думці, що саме техніки самоменеджменту можуть допомогти сучасній люди-

- сформувати системну концепцію особистого розвитку сучасного керівника.

Це завдання передбачає освоєння і реалізацію комплексу сучасних технологій та методів підвищення особистої ефективності, які б керівник, виходячи 3 конкретних умов, сфери діяльності, характеру обов'язків, чисельності підлеглих, зміг використовувати 3 метою підвищення ефективності як власної роботи, так і компанії в цілому.

Виклад основних результатів та їх обгрунтування. Системний підхід до проблеми управління власними ресурсами дозволив виділити кілька основних аспектів самоменеджменту:

- раціональне використання часу;

- прагнення виробити у себе адекватну самооцінку щодо наявності та розвитку компетенцій, яких вимагає від менеджера сучасне оточення;

- визначення і розвиток свого профілю інтелекту, сильних і слабких сторін своєї особистості;

- формування індивідуального ділового стилю поведінки;

- досягнення успіху в особистій діловій каp'єpi. ні впоратися зі складними проблемами, які неминуче супроводжують сучасне життя. Але ж поняття самоменеджмент найчастіше ототожнюється 3 поняттям тайм-менеджмент. Такі відомі сучасні автори як Г. Архангельський, П. Берд, Ф. Кей, М. Кук, Ф. О’Коннелл, Б. Трейсі, Д. Кеннеди також пов'язують вирішення проблеми підвищення особистої ефективності в основному з питання раціонального використання часу.

Але ж чи правильно концентрувати увагу тільки на управлінні часом, як основного ресурсу керівника? Вважаємо, що ні. При визначенні особистої ефективності необхідно враховувати витрати емоцій, здоров'я, матеріальних і фінансових ресурсів керівника тощо. Його зусилля повинні не тільки призводити до певного результату, а й приносити задоволення. Тільки тоді людина буде мотивована до ефективної праці. Про це свідчить відома модель ПортераЛоулера, яка показує наскільки важливо поєднати такі складові, як зусилля, здібності, результати, винагорода і задоволення в рамках єдиної взаємозв'язаної системи.

Саме тому з кінця XX століття самоменеджмент визначають як управління власними ресурсами, тобто вміння їх здобувати, зберігати, розвивати і раціонально використовувати і бути успішною, самодостатньою і задоволеною людиною. Проблемою остається формування такого підходу до самоменеджменту, який би забезпечив ефективність такого управління як на теоретико-методичному, так і на практичному рівнях.

Формулювання цілей дослідження. Реалізація на практиці сучасного погляду на самоменеджмент, як управління власними ресурсами, вимагає системного підходу до вибору відповідних методик і практик, що і обумовило ціль даного дослідження, а caмe

Саме завдяки оволодінню теорії і практики самоменеджменту керівник може відповісти на запитання:

- що саме обмежує особисту ефективність роботи? Які компетенції потребують розвитку? рівника?

- які сильні та слабкі сторони особистості ке-

- які ділові навички та якості потребують подальшого розвитку та удосконалення? свій час?

- як навчитися ефективно використовувати

- яка модель ділової кар'єри буде найбільш сприятливою 3 точки зору досягнення особистих i організаційних інтересів?

Наявності яких же компетенцій вимагає сьогодення від сучасного керівника? Узагальнюючи, вимоги, які висуваються до сучасного менеджера будь-якого рівня можна розділити на 6 основних блоків:

1. Знання спеціальності: знання технології виробничого процесу і його функціонування; знання теорії менеджменту, основних законів і принципів; знання загальної економічної теорії; знання теорії 
маркетингу; загальна ерудиція за фахом; знання науки психологія.

2. Особисті якості: уміння бути у відповідній формі (здоров'я, настрій, емоції тощо); витривалість у стані невизначеності й стресу; витримка в будь-якій конфліктній ситуації; комунікативність; уміння слухати; інтуїція; сприйнятливість критики, самокритичність; упевненість у собі; прагнення до успіху й готовність працювати для цього; вік і зовнішні дані.

3. Особисті здібності: уміння переконувати, харизма; уміння розподіляти обов'язки й давати чіткі вказівки; уміння стимулювати й мотивувати працівників; легкість у спілкуванні, тактовність і дипломатичність; організованість.
4. Інтелектуальні здатності: розум і розважливість; творчий потенціал; уміння приймати потрібні рішення; логічне, структурне, системне мислення.

5. Робочі навички (прийоми): раціональність $і$ системність у роботі; уміння максимально концентруватися, вирішувати проблеми; уміння виражати свої думки, вести переговори.

6. Фізичні можливості: активність і рухливість; енергійність, сила і здоров'я.

Сукупність різноманітних компетентностей i характеристик формує особистісний потенціал керівника, який має складну будову і відрізняється структурною єдністю всіх його елементів (рис 1) .

\begin{tabular}{|c|c|c|c|c|c|}
\hline \multicolumn{7}{|c|}{ Особистісний потенціал керівника } \\
\hline $\begin{array}{c}\text { Кваліфікаційний } \\
\text { потенціал }\end{array}$ & $\begin{array}{c}\text { Емоційний } \\
\text { потенціал }\end{array}$ & $\begin{array}{c}\text { Психофізіологічний } \\
\text { потенціал }\end{array}$ & $\begin{array}{c}\text { Комунікативний } \\
\text { потенціал }\end{array}$ & $\begin{array}{c}\text { Освітній } \\
\text { потенціал }\end{array}$ & $\begin{array}{c}\text { Творчий } \\
\text { потенціал }\end{array}$ \\
\hline
\end{tabular}

Рис.1. Структура потенціалу керівника*

*складено автором

Як бачимо, перелік професійних компетенцій сучасного менеджера - дуже різнобічний. Першими про еволюцію управлінських компетенцій заговорили наприкінці 1980-х років західні бізнес-школи $[4,5,6]$. Світова економіка розвивається настільки динамічно, що набір навичок, з якими керівники виходять на ринок праці, більше не зберігає актуальність на десять років вперед. Так сьогодні керівник більшою мірою повинен володіти не прикладними, а психологічними навичками. На перше місце постає вміння формувати особистісні відносини. Багато процесів зараз протікають на стику технологій, і керівник повинен не тільки добре розбиратися в цьому, а й знаходити вузьких фахівців 3 кожного напряму, щоб створювати комплексні команди для роботи в нових умовах. Саме тому, за твердженнями багатьох науковців і практиків менеджменту, все більшої актуальності для сучасного керівника набуває рівень емоційного потенціалу [7, 8, 9, 10].

Формування особистісного потенціалу керівника передбачає, з одного боку, освоєння і реалізацію комплексу сучасних професійних знань і практичних навичок, їх застосування, оволодіння ефективними навичками соціального управління та людськими технологіями, а 3 іншого боку, вміння визначити ту сферу і модель діяльності, в якій він зміг би «показати» найкращі результати. Саме на це і спрямована сучасна методологія самоменеджменту.

В науковій літературі останніх років виділилося два основних напрями самоменеджменту.

Жорсткий самоменеджмент - радикальні заходи для того, щоб все встигати. Ваша ефективність залежить від того, наскільки розумно ви використовуєте свій час і наскільки дозволяєте іншим його витрачати. Основу даного напряму і становлять технології тайм-менеджменту. Основний принцип жорсткого тайм-менеджменту - знання вартості хвилини вашого продуктивного часу змінює ваше життя [11].

Адаптивний самоменеджмент - інтегрована концепція, орієнтована на розкриття внутрішніх механізмів поведінки людини. Основний принцип адаптивної концепції самоменеджменту - замість того щоб змінювати обставини, які ми і так не в силах змінити, потрібно змінити своє ставлення до них, а це вимагає управління не часом, а собою, своїми ресурсами: розумовими, фізичними, психічними.

В процесі пошуку ефективних інструментів самоуправління i саморозвитку було сформовано умовно п'ять основних поглядів - концепцій самоменеджменту (табл. 1).

Таблиця 1

Концепції само менеджменту*

\begin{tabular}{|c|c|c|}
\hline $\begin{array}{c}\text { Автор } \\
\text { концепції }\end{array}$ & \multicolumn{1}{|c|}{ Основна ідея } & \multicolumn{1}{c|}{ Розуміння самоменеджменту } \\
\hline Лотар Зайверт [3] & економія свого часу & $\begin{array}{l}\text { самоменеджмент (time-management) - це послі- } \\
\text { довне і цілеспрямоване використання випробу- } \\
\text { ваних методів роботи в повсякденній практиці } \\
\text { для того, щоб оптимально використовувати свій } \\
\text { час }\end{array}$ \\
\hline
\end{tabular}


Продовження табл. 1

\begin{tabular}{|c|c|c|}
\hline $\begin{array}{c}\text { Автор } \\
\text { концепції }\end{array}$ & Основна ідея & Розуміння самоменеджменту \\
\hline $\begin{array}{l}\text { Майк Вудкок і Дэйв } \\
\text { Френсіс [2] }\end{array}$ & подолання власних обмежень & $\begin{array}{l}\text { самоменеджмент - це всебічний спосіб перевір- } \\
\text { ки своїх власних можливостей і обмежень і по- } \\
\text { шуку реальних шляхів розвитку особистісних і } \\
\text { ділових якостей }\end{array}$ \\
\hline В.А. Андрєєв [12] & саморозвиток творчої особистості & $\begin{array}{l}\text { самоменеджмент - це психологічний механізм } \\
\text { саморозвитку творчої особистості, здатної до } \\
\text { безупинного саморозвитку і самореалізації в } \\
\text { одному чи декількох видах професійної діяль- } \\
\text { ності }\end{array}$ \\
\hline А.Т. Хроленко [13] & $\begin{array}{l}\text { підвищення особистої культури } \\
\text { ділового життя }\end{array}$ & $\begin{array}{l}\text { самоменеджмент - це практикум підвищення } \\
\text { свого ділового потенціалу шляхом підвищення } \\
\text { рівня ділової культури в різних її аспектах }\end{array}$ \\
\hline $\begin{array}{l}\text { Бербель і Хайнц Шва- } \\
\text { льбе [14] }\end{array}$ & $\begin{array}{l}\text { досягнення особистого ділового } \\
\text { успіху }\end{array}$ & $\begin{array}{l}\text { самоменеджмент - це досягнення особистого } \\
\text { ділового успіху (ділової кар'єри) через самопі- } \\
\text { знання і самовдосконалення своїх ділових якос- } \\
\text { тей }\end{array}$ \\
\hline
\end{tabular}

*складено автором

Реалізація кожної концептуальної лінії передбачає використання різних підходів, методик, практик тощо.

Так концепиія Лотара Зайверта за своєю суттю представляє собою систему time-management. Ця концепція найбільш раціональна й універсальна, тому що вона містить у собі найбільш важливі моменти 3 інших концепцій і одночасно дає відпрацьовані й багаторазово випробувані методи роботи над со- бою, які не вимагають особливих мудрувань, багаторазового тестування й придатні для застосування в повсякденній практиці.

Систематизуючи ці методи роботи над собою, можна визначити декілька основних сфер таймменеджменту, які потребують системної дії, спрямованої на підвищення ефективності використання часу сучасного керівника (рис. 2).

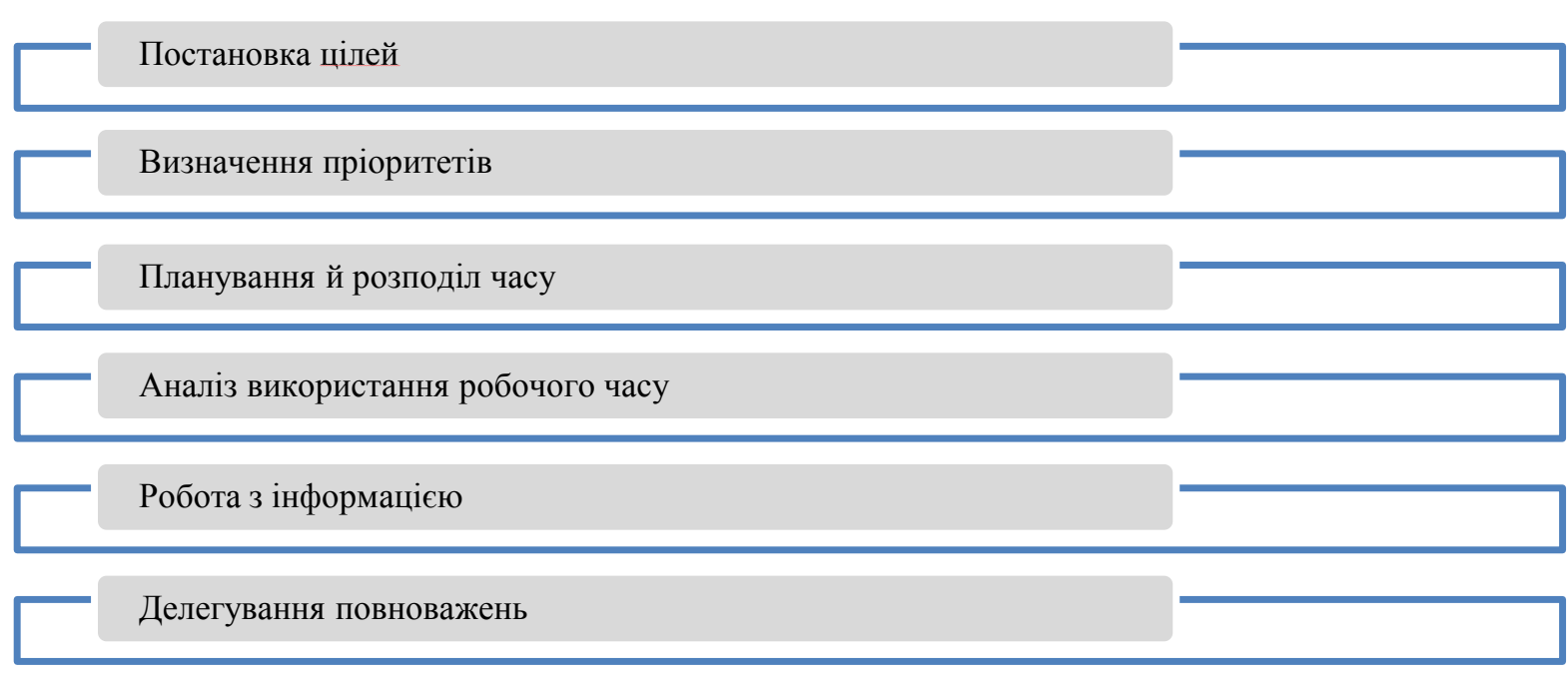

Рис. 2. Основні сфери тайм-менеджменту*

*складено автором

Кожна з названих сфер потребує використання цілої низки відомих інструментів: «колесо життєвого балансу», smart-технологія, інтелектуальні карти, «дерево цілей», ВАК-образи - для ефективної постановки цілей; матриця Д. Ейзенхауера, аналіз АБВ - для визначення пріоритетів у виконанні завдань; принцип Парето, метод «Альпи», Методика Getting Things Done (GTD) Девіда Аллена, SCRUM-дошка, метод швейцарського сиру», «3'їдати слона по шма- точках», метод «Помідора» і багато інших інструментів - при плануванні та розподілі часу; хронометраж - для аналізу використання робочого часу; правила маркування тексту, інсерт-технологія, кластерна форма передачі інформації, техніка швидкочитання тощо - для підвищення ефективності роботи з великою кількістю інформації; матриця обов'язків та безліч різних професійних порад стосовно правил ефективного делегування $[3,11,15,16,17,18]$. 
Методика самоменеджменту за обмеженнями М. Вудкока і Д. Френсіса [2] передбачає дослідження 3 використанням тестів своїх особистих обмежень, уточнення, у чому вони полягають, погляд на свої обмеження очима оточуючих і $з$ позицій вимог безпосередньої роботи й, нарешті, практичне керівництво “Як подолати обмеження ".

Так автори у якості орієнтирів у саморозвитку розглядають наступні критерії ефективного управління, які й підлягають оцінці і розвитку: здатності керувати собою; розуміння особистих цінностей; чіткі особисті цілі; постійне особисте зростання; навички вирішувати проблеми; винахідливість і здатність до інновацій; висока здатність впливати на оточуючих; знання сучасних управлінських підходів; здатність керувати емоціями; уміння навчати і розвивати підлеглих; здатність формувати і розвивати ефективні робочі групи.

Застосовуючи цей підхід, керівник зможе спрямувати свої зусилля на отримання чи удосконалення саме тих якостей і компетенцій, які на даний час обмежують його ефективність.

Центральна ідея кониепиї̈ B.I. Андрєєва [12] полягає у виділенні в якості інтегральної узагальненої характеристики сучасного менеджера, творчого характеру його особистості, тобто особистості, здатної до безперервного саморозвитку й самореалізації в одно- му, а найчастіше в декількох видах професійнотворчої діяльності. Знання своїх індивідуальних особливостей і здатностей дуже важливо, тому що це, по суті, знання своїх гідностей і недоліків. Визначення свого типу особистості дозволяє побудувати «профіль особистості», визначити їі сильні й слабкі сторони. Для реалізації даного підходу можуть бути застосовані різні методики, наприклад відома ТАРТметодика (визначення ділового профілю особистості по Тайгеру [19]).

Вихідною позицією для саморозвитку є визначення свого типу особистості, виходячи з 16 показників різних типів творчих особистостей менеджерів (рис. 3), за чотирьма критеріями:

екстраверсія (Е) - інтроверсія (I) (тип особистості описує те, як ми вважаємо за краще взаємодіяти з навколишнім світом і куди спрямовуємо свою енергію);

сенсорика (С) - інтуїція (Н) (особливості сприйняття інформації: факти, органи чуття / значення фактів, їх інтерпретація, сенс)

раціональність (Р) - ірраціональність (Ц) (особливості прийняття рішення: неупереджене, об'єктивне, логічне /індивідуальні переваги)

статика (Т) - динаміка (Д) (наші переваги між життям в організованому світі і більш вільним способом життя).

\begin{tabular}{|llll|}
\hline ІСРТ & ІСЦТ & ІНЦТ & ІНРТ \\
ІСРД & ІСЦД & ІНЦД & ІНРД \\
ЕСРД & ЕСЦД & ЕНЦД & ЕНРД \\
ЕСРТ & ЕСЦТ & ЕНЦТ & ЕНРТ \\
\hline
\end{tabular}

Рис. 3. Шістнадцять типів особистості [20]

Для кожного типу особистості існує одна функція, яка для даного типу має основне значення. Їі називають домінантною функцією, тобто основною. Основною може бути будь-яка 3 чотирьох функцій (сенсорика, інтуїція, раціональність, ірраціональність), але для кожного типу особистості існує тільки одна основна функція, і вона завжди залишається такою. Наступна функція в ієрархії називається допоміжною функцією. У кожного типу особистості існує тільки одна допоміжна функція і ії положення ніколи не змінюється (рис. 4).

Як в роботі використовувати свої сильні сторони і звести до мінімуму недоліки (слабкі сторони)? Ваші найсильніші сторони відображені у вашій основній та допоміжній функціях. Але коли ви користуєтеся четвертою і до певної міри третьою функцією, то відразу ж виявляєте свої слабкі місця. Якщо ви дієте відповідно до ваших природніх (вроджених) сильних сторін, то відчуваєте підйом, але якщо дієте зі своїх слабких позицій, ви відразу ж стаєте занадто уразливими і відчуваєте велике напруження. Як правило, чим більше сторін характеру збігається 3 вимогами обраної професії, тим більше задоволення від роботи можна отримати, тим більшого успіху можна досягти.

Концепиія А. Т. Хроленко [13] заснована на ідеї культури ділового життя. Згідно із цією концепцією, самоменеджмент - це практикум підвищення свого ділового потенціалу шляхом підвищення рівня ділової культури в різних iї аспектах, а саме:

- культури взаємин між людьми;

- мистецтва ділової бесіди;

- організації ділової наради;

- культури ділового листування;

- мистецтва підготовки доповіді й публічного виступу;

- техніки особистої роботи;

- стилю життя менеджера. 


\begin{tabular}{|c|c|c|c|}
\hline $\begin{array}{l}\text { ІСРТ } \\
\text { 1. Сенсорика } \\
\text { 2. Раціональність } \\
\text { 3. Ірраціональність } \\
\text { 4. Інтуїція }\end{array}$ & $\begin{array}{l}\text { ІСЦТ } \\
\text { 1. Сенсорика } \\
\text { 2. Ірраціональність } \\
\text { 3. Раціональність } \\
\text { 4. Інтуїція }\end{array}$ & $\begin{array}{l}\text { ІНЦТ } \\
\text { 1. Інтуїція } \\
\text { 2. Ірраціональність } \\
\text { 3. Раціональність } \\
\text { 4. Сенсорика }\end{array}$ & $\begin{array}{l}\text { ІНРТ } \\
\text { 1. Інтуїція } \\
\text { 2. Раціональність } \\
\text { 3. Ірраціональність } \\
\text { 4. Сенсорика }\end{array}$ \\
\hline $\begin{array}{l}\text { ІСРД } \\
\text { 1. Раціональність } \\
\text { 2. Сенсорика } \\
\text { 3. Інтуїція } \\
\text { 4. Ірраціональність }\end{array}$ & $\begin{array}{l}\text { ІСЦД } \\
\text { 1. Ірраціональність } \\
\text { 2. Сенсорика } \\
\text { 3. Інтуїція } \\
\text { 4. Раціональність }\end{array}$ & $\begin{array}{l}\text { ІНЦД } \\
\text { 1. Ірраціональність } \\
\text { 2. Інтуїція } \\
\text { 3. Сенсорика } \\
\text { 4. Раціональність }\end{array}$ & $\begin{array}{l}\text { ІНРД } \\
\text { 1. Раціональність } \\
\text { 2. Інтуїція } \\
\text { 3. Сенсорика } \\
\text { 4. Ірраціональність }\end{array}$ \\
\hline $\begin{array}{l}\text { ЕСРД } \\
\text { 1. Сенсорика } \\
\text { 2. Раціональність } \\
\text { 3. Ірраціональність } \\
\text { 4. Інтуїія } \\
\end{array}$ & $\begin{array}{l}\text { ЕСЦД } \\
\text { 1. Сенсорика } \\
\text { 2. Ірраціональність } \\
\text { 3. Раціональність } \\
\text { 4. Інтуїція } \\
\end{array}$ & $\begin{array}{l}\text { ЕНЦД } \\
\text { 1. Інтуїція } \\
\text { 2. Ірраціональність } \\
\text { 3. Раціональність } \\
\text { 4. Сенсорика } \\
\end{array}$ & $\begin{array}{l}\text { ЕНРД } \\
\text { 1. Інтуїція } \\
\text { 2. Раціональність } \\
\text { 3. Ірраціональність } \\
\text { 4. Сенсорика } \\
\end{array}$ \\
\hline $\begin{array}{l}\text { ЕСРТ } \\
\text { 1. Раціональність } \\
\text { 2. Сенсорика } \\
\text { 3. Інтуӥція } \\
\text { 4. Ірраціональність }\end{array}$ & $\begin{array}{l}\text { ЕСЦТ } \\
\text { 1. Ірраціональність } \\
\text { 2. Сенсорика } \\
\text { 3. Інтуїція } \\
\text { 4. Раціональність }\end{array}$ & $\begin{array}{l}\text { ЕНЦТ } \\
\text { 1. Ірраціональність } \\
\text { 2. Інтуїція } \\
\text { 3. Сенсорика } \\
\text { 4. Раціональність }\end{array}$ & $\begin{array}{l}\text { ЕНРТ } \\
\text { 1. Раціональність } \\
\text { 2. Інтуїція } \\
\text { 3. Сенсорика } \\
\text { 4. Ірраціональність }\end{array}$ \\
\hline
\end{tabular}

Рис. 4. Ієрархія функцій кожного типу особистості [19]

Розширення професійних можливостей особистості в результаті роботи з підвищення своєї ділової кваліфікації створює основу для службового росту. Відповідно до такого розуміння самоменеджмент являє собою набір корисних міркувань і практичних ділових порад для підвищення свого рівня ділової культури в різних іiї аспектах. Сьогодні на ринку навчальних послуг існує безліч пропозицій щодо професійних тренінгів, семінарів тощо, за різними напрямами розвитку навичок ділової культури.

Згідно з конщепиією Бербеля і Хайнща Швальбе [14], самоменеджмент- це досягнення особистого ділового успіху (ділової кар'єри) через самопізнання й самовдосконалення своїх ділових якостей. Автори концепції Бербель і Хайнц Швальбе в якості центральної ідеї обрали зв'язок кар'єри з успіхом. Саме оріє- нтація на досягнення успіху, тобто результату діяльності, співвіднесеного $з$ очікуваннями, системою цінностей, життєвими цілями індивіда, а також одержанням позитивної суспільної й соціальної оцінки, служить головним мотивом просування по щаблях ділової кар'єри. Їх аналіз показує, що для досягнення успіху необхідна особиста концепція ділової кар'єри, що об'єктивно враховує власні гідності й недоліки й орієнтована на свої уявлення про успіх (рис. 5).

Для визначення «своєї» моделі ділової кар'єри можна рекомендувати використання методики «Якір кар'єри» Е. Шейна [20], яка на підставі відповідей на сукупність питань дає змогу визначитися 3 тією формою вашого ділового розвитку, яка б забезпечила не тільки професійні досягнення, а й збереження вашого емоційного комфорту на все життя.

\begin{tabular}{|c|c|}
\hline Кар'єрна орієнтація & 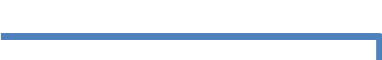 \\
\hline Професійна компетентність & $\longrightarrow$ \\
\hline Менеджмент & \\
\hline Автономія (незалежність) & \\
\hline Стабільність роботи & \\
\hline Стабільність місця проживання & \\
\hline Служіння & \\
\hline Виклик & \\
\hline Інтеграція стилів життя & \\
\hline Підприємництво & \\
\hline
\end{tabular}

Рис. 5. Види особистої концепції ділової кар'єри [14] 
Висновки та перспективи подальших досліджень. Що дає нам таке системне бачення проблем самоменеджменту? Саме комплексний, системний підхід до процесу підвищення особистої ефективності і саморозвитку дає можливість керівникові отримати від своєї діяльності не тільки значного професійного ефекту, але й задоволення від самого процесу праці за рахунок: правильного визначення сфери своєї професійної діяльності, в якій будуть цілком використані його сильні особисті характеристики і компетенції; розширення професійних можливостей і рівня ділової культури; розуміння своїх обмежень і намагання їх усунути; вміння застосовувати ефективні практики тайм-менеджменту; формування раціональної особистої концепції ділової кар'єри.

Подальші дослідження проблем самоменеджменту сучасного керівника безумовно будуть включати ще більше коло аспектів, пов'язаних із забезпеченням не тільки ефективності праці у звичному розумінні, але й задоволення та емоційного комфорту і керівника, і всього колективу, а саме питанням стресостійкості, емпатії, здорового способу життя тощо.

\section{Література}

1. Тоффлер Э. Шок будущего. М.: АСТ, 2001. 560 с.

2. Вудкок М., Фрэнсис Д. Раскрепощенный менеджер: для руководителя-практика. М.: Дело, 2001. 320

c.

3. Зайверт Л. Ваше время - в ваших руках. Советы руководителям, как эффективно использовать рабочее время / Зайверт Л.; пер. с нем. Цедилин Л. М.: Экономика, 2001. 267 с.

4. Cleveland G., Schroeder R.G. and Anderson J.C. A theory of production competence // Decision Science. 1989. Vol. 20, pp. 655-668

5. Corbett C. and Van Wassenhove L. (1993), "Trade-off? What trade-off? Competence and competitiveness in manufacturing strategy", California Management Review, Summer, pp. 107-122.

6. Vickery S.K. Theory of production competence revisited // Decision Sciences, 1991. Vol. 22. №. 3, pp. 635-643.

7. Бєлікова Ю.В. Емоційний профіль лідера // Соціальна психологія: укр. наук. журн. Київ, 2012. №1/2 (52). С .283-293.

8. Дерев'янко С. Актуалізація емоційного інтелекту в емоціогенних умовах // Соціальна психологія. 2008. №1 (27). С. 96-104.

9. Книш А. Є. Емоційний інтелект лідера у сфері бізнесу: навч. посібник / за заг. ред. О. Г. Романовського, С. В. Калашникової. К.: ДП «НВЦ Пріоритети», 2016. 40 с.

10. Филатова О. Эмоциональний интеллект как показатель целостного развития личности // Персонал. № 5.2000 .243 c.

11. Кеннеди Д. Жесткий тайм-менеджмент. Возьмите свою жизнь под контроль / Кеннеди Д.; пер. с англ. Посредникова А. М: «Альпина Паблишер», 2018, 199 с.

12. Андреев В. И. Конфликтология: искусство спора, ведение переговоров, разрешение конфликтов. М.: Народное образование, 1995. $178 \mathrm{c.}$

13. Хроленко А. Т. Самоменеджмент: для тих, кому від 16 до 20. М.: Економіка, 1996. 139с.

14. Швальбе Б. Личность, карьера, успех / Швальбе Б., Швальбе Х.; пер. с нем. Л.Н. Цедилина; под ред. В.В. Шолерова. М.: АО Издат. Группа «Прогресс-Интер», 1993. 228 с.

15. Архангельский Г.А. Организация времени. От личной эффективности к развитию фирмы: учеб. пособие. 2-е изд. СПб.: Питер, 2006. 448 с. 2018. $128 \mathrm{c}$

16. Трейсі Б. Делегування \& керування, Видавництво: Книжковий клуб «Клуб сімейного дозвілля»,

17. Свтушенко Г.І. Аналіз стану управління робочим часом та шляхи підвищення ефективності застосування «тайм-менеджменту» // Збірник наукових праць Національного університету державної податкової служби України / Національний університет ДПС України, Ірпінь, 2014. № 1. С. 88-96.

18. Маккензи Р.А. Ловушка времени: рекомендации, примеры, советы. М.: Вече : Персей: АСТ, 2005. $479 \mathrm{c}$.

19. Тигер П., Бэррон-Тигер Б. Делай то, для чего ты рожден: Путь к успешной карьере через самопознание / Тигер П., Бэррон-Тигер Б.; пер. с англ. Н. Б. Демченко. М.: АРМАДА, 1996.

20. Шейн Э. Организационная культура и лидерство. СПб.: Питер, 2008. - 336 с.

Стаття надійшла 21.01.2019

Стаття прийнята до друку 3.02.2019

Доступно в мережі Internet 19.03.2019 


\author{
Корсикова Н.Н. \\ кандидат экономических наук, доцент \\ E-mail:nkorsikova@ukr.net \\ ORCID ID: 0000-0002-1649-4725 \\ Череватый В.H. \\ магистрант \\ кафредра менеджмента и логистики \\ Одесская национальная академия пищевых технологий \\ Ул. Канатная,112,г. Одесса, Украина, 65039 \\ E-mail: v_cherevatyi@ukr.net
}

\title{
СИСТЕМНЫЙ ПОДХОД К ПОВЫШЕНИЮ ЛИЧНОЙ ЭФФЕКТИВНОСТИ СОВРЕМЕННОГО РУКОВОДИТЕЛЯ
}

\begin{abstract}
Сегодня назрела необходимость применения новых подходов к фрормированию современного эффективного руководителя, что повышает значимость самоменеджмента как в теоретикометодическом, так и практическом его аспектах. В статье рассмотрена актуальность и основные аспекты работы современного руководителя, его место и значение в современном обществе, представлены основные фракторы внешней среды, которые обусловливают необходимость усиления внимания руководителя к формированию и постоянному развитию совокупности компетенций, способствующих не только его личной эффективности, но и эффективности всей компании; определена структура ключевых профессиональных компетенций и требований к качествам современного менеджера.

Учитывая сложность и многоаспектность приведенной системы требований и компетенций, выделено несколько основных аспектов самоменеджмента, как современной научной системы знаний по развитию и повышению личной эффрективности руководителя. В работе охарактеризованы основные концептуальные взгляди на проблемы самоменеджмента; предложено обратить внимание на отдельные практические методические приемы реализации каждого концептуального направления.

Представлена система критериев эффективного управленца, требующих соответствующей оценки и развития; обоснована целесообразность определения «личного кода» руководителя и типа его деловой карьеры, использования различных приемов тайм-менеджмента, как весомых фракторов, обусловливающих способность эффективно использовать собственные ресурсы, управлять собой и другими людьми.

Авторы приходят к выводу, что именно комплексный, системный подход к процессу повышения личной эффективности и саморазвития дает возможность руководителю получить от своей деятельности не только значительный профессиональный эффект, но и удовлетворение от самого процесса работы.

Ключевые слова: личная эффективность, руководитель, компетенции, самоменеджмент, тайм-менеджмент, личностное развитие.
\end{abstract}

\author{
Korsikova N. \\ Ph.D., Associate Professor \\ E-mail:nkorsikova@ukr.net \\ ORCID ID: 0000-0002-1649-4725 \\ Cherevatyi V. \\ Undergraduate \\ Department of Management and Logistics \\ Odessa National Academy of Food Technologies \\ Kanatna str., 112, Odesa, Ukraine, 65039 \\ E-mail:v_cherevatyi@ukr.net
}

\section{SYSTEM APPROACH TO INCREASE OF PERSONAL EFFICIENCY OF THE MODERN MANAGER}

Today, there is a growing necessity of applying new approaches to the formation of a modern effective leader, which increases the significance of self- management in both theoretical and methodological and practical aspects.

The article considers the relevance and main aspects of the work of a modern leader, his place and importance in the modern society, examines the main factors of the environment, which determine the need to increase the attention of the head to the formation and continuous development of a set of competencies that contribute not only to its personal effectiveness, but also to the effectiveness of the entire 
company; the structure of key professional competencies and requirements to the qualities of a modern manager is determined.

Taking into account the complexity and multidimensionality of the given system of requirements and competencies, several main aspects of self-management, as a modern scientific system of knowledge on development and increase of personal efficiency of any person are allocated. The paper describes the main conceptual views on self-management problems; it is suggested to pay attention to individual practical methodical techniques for the implementation of each conceptual direction.

The system of criteria for an effective manager, which requires an appropriate assessment and development has been presented; the expediency of determining the "personal code" of the manager and the type of his business career has been justified, the use of different techniques of time management, as the weighty factors that determine the ability to effectively use their own resources, manage themselves and other people has also been substantiated.

The authors come to the conclusion that it is a comprehensive, systematic approach to the process of increasing one's own efficiency and self-development that enables the manager to get from his activity not only a significant professional effect, but also satisfaction from the working process itself. development.

Key words: efficiency, manager, competencies, self-management, time management, personal

\section{References}

1. Toffler, E. (2001). Shok buduschego. Moscow: AST.

2. Vudkok, M., \& Frensis, D. (2001). Raskreposchennyiy menedzher: Dlya rukovoditelya-praktika. Moscow:

Delo.

3. Zayvert, L. (2001). Vashe vremya - v vashih rukah. Sovetyi rukovoditelyam, kak effektivno ispolzovat rabochee vremya (L. Tsedilin, Trans.). Moscow: Ekonomika.

4. Cleveland, G., Schroeder, R. G., \& Anderson, G. C. (1989). A theory of production competence. Decision Science, 20, 655-668.

5. Corbett, C., \& Van Wassenhove, L. (1993). Trade-off? What trade-off? Competence and competitiveness in manufacturing strategy [Review]. California Management Review, 107-122.

6. Vickery, S. K. (1991). Theory of production competence revisited. Decision Sciences, 22(3), 635-643.

7. Bielikova, Yu. V. (2012). Emotsiinyi profil lidera. Sotsialna Psykholohiia, (1/2 (52)), 283-293.

8. Derev'ianko, S. (2008). Aktualizatsiia emotsiinoho intelektu v emotsiohennykh umovakh. Sotsialna Psykholohiia, (1 (27)), 96-104.

9. Knysh, A. Ye. (2016). Emotsiinyi intelekt lidera u sferi biznesu (O. H. Romanovskyi \& S. V. Kalashnykova, Eds.). Kyiv: DP «NVTs Priorytety».

10. Filatova, O. (2000). Emotsionalniy intellekt kak pokazatel tselostnogo razvitiya lichnosti. Personal,(5).

11. Kennedi, D. (2018). Zhestkiy taym-menedzhment. Vozmite svoyu zhizn pod kontrol (A. Posrednikova, Trans.). Moscow: «Alpina Pablisher».

12. Andreev, V. I. (1995). Konfliktologiya: Iskusstvo spora, vedenie peregovorov, razreshenie konfliktov. Moscow: Narodnoe obrazovanie.

13. Khrolenko, A. T. (1996). Samomenedzhment: Dlia tykh, komu vid 16 do 20. Moscow: Ekonomika.

14. Shvalbe, B., \& Shvalbe, H. (1993). Lichnost, karera, uspeh (L. N. Tsedilina, Trans.; V. V. Sholerov, Ed.). Moscow: AO Izdat. Gruppa «Progress-Inter».

$\mathrm{SPb} .:$ Piter.

15. Arhangelskiy, G. A. (2006). Organizatsiya vremeni. Ot lichnoy effektivnosti k razvitiyu firmyi (2nd ed.). lia».

16. Treisi, B. (2018). Delehuvannia \& keruvannia. Vydavnytstvo: Knyzhkovyi klub «Klub simeinoho dozvil-

17. Yevtushenko, H. I. (2014). Analiz stanu upravlinnia robochym chasom ta shliakhy pidvyshchennia efektyvnosti zastosuvannia «taim-menedzhmentu». Zbirnyk Naukovykh Prats Natsionalnoho Universytetu Derzhavnoi Podatkovoi Sluzhby Ukrainy, (1), 88-96.

18. Makkenzi, R. A. (2005). Lovushka vremeni: Rekomendatsii, primeryi, sovetyi. Moscow: Veche : Persey: AST.

19. Tiger, P., \& Berron-Tiger, B. (1996). Delay to, dlya chego tyi rozhden: Put $k$ uspeshnoy karere cherez samopoznanie (N. B. Demchenko, Trans.). Moscow: ARMADA.

20. Sheyn, E. (2008). Organizatsionnaya kultura i liderstvo. SPb.: Piter.

Received 21 January2019

Approved 3 February 2019

Available in Internet 19.03.2019

Цитування згідно ДСТУ 8302:2015

Корсікова Н.М., Череватий В.М. Системний підхід до підвищення особистої ефективності сучасного керівника // Економіка харчової промисловості. 2019. Т.11, вип. 1. С. 80-88; doi: 10.15673/fie.v11i1.1298

Cite as APA style citation

Korsikova N., \& Cherevatyi V. (2019). System approach to increase of personal efficiency of the modern manager. Food Industry Economics, 11(1), 80-88; doi: 10.15673/fie.v11i1.1298 